\title{
PERBANDINGAN KEJADIAN PRE EKLAMSIA DI RUMAH SAKIT DAERAH PANTAI DAN PEGUNUNGAN DI JAWA BARAT
}

\author{
Susanti ${ }^{1}$ \\ 1 Fakultas Ilmu Kesehatan Universitas Borneo Tarakan \\ *Email: shantie.alfarisi@gmail.com
}

\begin{abstract}
Abstrak
Pre eklamsia merupakan penyebab kematian ibu terbanyak disamping perdarahan dan infeksi. Penelitian ini bertujuan untuk mengetahui perbandingan kejadian pre eklamsia daerah pantai dan pegunungan di Jawa Barat. Penelitian bersifat deskrptif dengan menggunakan pendekatan cross sectional. Sampel yang diambil adalah ibu ibu dengan kasus preeklamsia yang melahirkan di RSUD Gunung Jati Cirebon dan RSKIA Kota Bandung dengan teknik pengambilan sampel secara acak sistematik (Systematic Sampling) yang dilakukan pada tanggan 17 Juli 2008 sampai dengan 13 Agustus 2008. Data sekunder diperoleh dari catatan rekam medik pasien rawat inap. Terdapat 1748 jumlah populasi dengan kasus preeklamsia paling banyak terjadi di daerah pantai $(13,43 \%)$ dan paling banyak terjadi pada umur $>35$ tahun $(34,2 \%)$. Jumlah paritas yang paling banyak terjadi preeklamsia 0 - 1. Kasus preeklamsia yang terjadi pada usia kehamilan 33 - 37 minggu paling banyak terjadi di daerah pantai (92,6\%), sedangkan di pegunungan paling banyak terjadi pada usia kehamilan > 37 minggu (16\%). Cara persalinan yang paling sering dilakukan adalah pervaginam, sedangkan komplikasi yang paling banyak terjadi adalah BBLR dan paling banyak ditemui di daerah pegunungan yaitu 74 kasus $(26,5 \%)$.
\end{abstract}

Kata kunci : pantai, pegunungan, preeklamsia

\begin{abstract}
Comparison of Pre Eklamsia-Events In Mountains And Coastal Hospital In West Java. Pre-eclampsia is the leading cause of maternal death beside the bleeding and infection. This study aims to determine the comparison of pre-eclampsia events coastal areas and mountains in West Java. The research was descriptive using cross sectional approach. Samples taken were mothers with cases of preeclampsia that gave birth at RSUD GunungJati Cirebon and RSKIA Bandung with systematic sampling technique (Systematic Sampling) conducted on July 17, 2008 until August 13, 2008. Secondary data obtained from the record medical records of inpatients. There are 1748 population with most cases of preeclampsia in coastal area $(13,43 \%)$ and most occur at age $>35$ years $(34,2 \%)$. the number of parity most common happened pre-eclampsia 0 - 1 . Cases of preeclampsia that occur at 33-37 weeks of pregnancy most common in coastal area $(92,6 \%)$, while in mountains most happened at gestation $>37$ weeks $(16 \%)$. The most common mode of delivery is vaginal, while the most frequent complications are LBW and most commonly found in mountainous areas is 74 cases $(26.5 \%)$.
\end{abstract}

Keywords : coastal shore, mountain range, pre-eclamsia 


\section{Pendahuluan}

Berdasarkan data SDKI tahun 2002, AKI adalah 307 per 100.000 kelahiran hidup. Angka ini merupakan tertinggi di ASEAN. Angka kematian ibu di Indonesia ini bahkan lebih jelek dari negara Vietnam. Angka kematian ibu di Negara tetangga itu pada tahun 2003 tercatat 95 per 100.000 kelahiran hidup. Di negara Malaysia tercatat 30 per 100.000 kelahiran hidup. Sedangkan Singapura 9 per 100.000 kelahiran hidup $(0,13 \%)$.

Di Indonesia kejadian penyakit ini sangat bervariasi. Provinsi DKI Jakarta yang letak daerahnya sangat rendah yaitu sekitar 7 meter di atas permukaan laut tercatat kejadian preeklamsia di salah satu rumah sakit yaitu RSPAD Gatot Soebroto periode 1 Januari sampai dengan 31 Desember 2004 sebanyak 4 kasus preeklamsia ringan $(1,04 \%)$ dan 33 kasus $(8,62 \%)$ preeklamsia berat dari 383 jumlah ibu yang bersalin.

Berdasarkan SDKI tahun 2012, rata-rata angka kematian ibu (AKI) tercatat sampai 359 per 100.000 kelahiran hidup. Hal ini mengungkapkan bahwa angka kematian ibu (AKI) mengalami peningkatan dari tahun 2007 yang mencapai 228 per 100.000 kelahiran hidup. Mortalitas dan morbiditas pada wanita hamil dan bersalin adalah masalah besar baik di negara berkembang maupun di negara miskin, di negara berkembang lebih dari $50 \%$ kematian ibu sebenarnya dapat dicegah dengan teknologi yang ada serta biaya yang relatif rendah, sedangkan di negara miskin sekitar $2550 \%$ kematian wanita usia subur yang disebabkan karena hal lain yang berkaitan dengan kehamilan, persalinan, dan nifas.

Angka kematian ibu di provinsi Jawa Timur juga masih tinggi. Berdasarkan laporan dari kabupaten/kota pada tahun 2013 didapat angka sebesar 107/100.000 kelahiran hidup. Penyebab kematian adalah perdarahan 23,19\%, eklamsi sebesar 39,38\%, infeksi sebesar $6,17 \%$ dan lain-lain sebesar $31,26 \%$.

Di Banjarmasin, Kalimantan Selatan yang secara topografi sebagian besar daerahnya datar/rata dan cenderung rawa dan rawan banjir dengan ketinggian 0,16 meter di atas permukaan laut, angka kejadian preeklamsia dari tahun 1998 sampai 2000 sekitar 11,4\% dari 5165 persalinan.

Penelitian yang dilakukan oleh Puslitbangkes Depkes RI Surabaya di beberapa daerah datar dan pesisir pantai, data yang didapatkan dari RSUD Padang Pariaman RSUD Sikka, NTT dengan rata - rata ketinggian antara 2 - 35 meter 
di atas permukaan laut dengan daerah lautan lebih luas dibanding dengan daratan, kejadian preeklamsia sebanyak $8,33 \%$ di tahun 2005 .

Di Jawa Barat, Bandung sebagai ibukota propinsi yang berada di ketinggian $768 \mathrm{~m}$ di atas permukaan air laut yang sebagian besar daerahnya dikelilingi oleh pegunungan walaupun ada beberapa tempat yang rendah dan rata, kejadian preeklamsia ini juga masih menjadi penyebab nomor satu kematian ibu dan merupakan kasus yang paling banyak ditemukan. Dari data yang didapat dari Rumah Sakit Hasan Sadikin tahun 2001 - 2002 tercatat 353 kasus preeklamsia $(10,3 \%)$ dari 3417 persalinan. Pada tahun 2003 - 2004 sebanyak 281 kasus $(11,36 \%)$ dari 2473 persalinan. Kemudian di tahun 2005 terdapat sebanyak 105 kasus preeklamsia $(5,36 \%)$ dari 1958 persalinan.

Sama halnya dengan di Kabupaten Subang yang di sebagian besar wilayah terdiri dari pegunungan, bukit bukit/bergelombang dan dataran rendah/pantai di daerah Subang bagian utara. Angka kejadian preeklamsia di daerah ini juga masih menjadi primadona yaitu tahun 2004 tercatat 280 kasus (12,97\%) dari 2159 persalinan.

Dari uraian singkat di atas kejadian preeklamsia di daerah pantai lebih tinggi daripada di daerah pegunungan, maka dilakukan penelitian terhadap daerah di wilayah pegunungan dan pantai di propinsi Jawa Barat. Namun, karena keterbatasan peneliti, maka penelitian ini hanya dilakukan di Kabupaten Cirebon dan Kota Bandung yang masing-masing mewakili daerah pantai dan pegunungan di Jawa Barat. Untuk itu penelit ingin mengetahui perbandingan kejadian preeklamsia diantara daerah-daerah tersebut secara terpisah antara kawasan sekitar pegunungan dan tepi pantai (pesisir). Selain itu, belum adanya penelitian yang dilakukan sebelumnya untuk membandingkan besarnya kejadian preeklamsia antara daerah pantai dan pegunungan.

\section{Metode}

Penelitian ini bersifat retrospektif dengan pendekatan cross-sectional dan dilakukan pada periode tahun 2005 sampai dengan tahun 2007 di RSUD Gunung Jati Cirebon yang berada di ketinggian 25 - $100 \mathrm{~m}$ di atas permukaan laut sehingga termasuk daerah dataran rendah/pantai dan RSKIA Kota Bandung yang berada pada ketinggian $768 \mathrm{~m}$ di atas permukaan laut yang termasuk daerah dataran tinggi/pegunungan. Populasi penelitian adalah seluruh ibu ibu yang pernah melahirkan dengan 
kasus preeklamsia di daerah pantai dan pegunungan dalam rentang waktu tiga tahun terakhir yaitu antara tahun 2005 sampai dengan tahun 2007 di RSUD Gunung Jati Cirebon dan RSKIA Kota Bandung yang berjumlah 1748 kasus yang terdiri dari 914 kasus di daerah pantai dan 834 kasus di daerah pegunungan. Dengan demikian besarnya sampel penelitian adalah 325 penderita preeklamsia untuk daerah pantai dan pegunungan.

\section{Hasil}

\section{Umur}

Hasil penelitian kejadian preeklamsia menurut umur pasien saat dirawat di RSUD Gunung Jati pada kelompok umur 18 - 23 tahun sebanyak 41 (12,6\%), kelompok umur $24-29$ tahun 80 (24,6\%), kelompok umur 30 35 tahun sebanyak 93 orang $(28,6 \%)$, dan kelompok umur $>35$ tahun sebanyak 111 (34,2\%). Di RSKIA Bandung pada kelompok umur 18 - 23 tahun sebanyak 55 orang $(16,9 \%)$, kelompok umur $24-$ 29 tahun 87 orang $(26,8 \%)$, umur $30-$ 35 tahun sebanyak 93 orang $(28,6 \%)$ dan kelompok umur $>35$ tahun sebanyak 90 orang $(27,7 \%)$.

\section{Paritas}

Kejadian preeklamsia menurut paritas di RSUD Gunung Jati pada kelompok paritas $0-1$ sebanyak 148 orang (45,5\%), kelompok 2 - 4 sebanyak 120 pasien $(36,9 \%)$ dan 57 kejadian pada kelompok paritas > $4(17,5 \%)$. Sedangkan di RSKIA Bandung kejadian preeklamsia pada kelompok paritas $0-1$ sebanyak 174 orang $(53,5 \%)$, kelompok paritas $2-4$ sebanyak $135(41,5 \%)$ dan $4,9 \%$ pada kelompok paritas $>4$.

\section{Usia Kehamilan}

Hasil penelitian kejadian preeklamsia menurut usia kehamilan di RSUD Gunung Jati pada kelompok 28 32 minggu sebanyak 16 pasien $(4,9 \%)$, usia kehamilan $33-37$ minggu sebanyak $301 \quad(92,6 \%)$, dan usia kehamilan $>37$ minggu sebanyak 8 orang $(2,5 \%)$. Sedangkan kejadian preeklamsia di RSKIA Bandung pada usia kehamilan 28 - 32 minggu sebanyak 18 orang (5,5\%), usia kehamilan 33 - 37 minggu sebanyak 255 orang $(78,5 \%)$ dan pada usia kehamilan > 37 minggu terjadi 52 kasus preeklamsia (16\%).

\section{Cara Persalinan}

Hasil penelitian menurut cara persalinan di RSUD Gunung Jati sebanyak $290 \quad(89,2 \%)$ dengan cara pervaginam dan sebanyak $35(10,8 \%)$ perabdominal. Sedangkan di RSKIA Bandung sebanyak 259 dengan persalinan pervaginam $(79,7 \%)$ dan $20,3 \%$ dengan cara perabdominal. 


\section{Komplikasi}

Hasil penelitian menurut komplikasi di RSUD Gunung Jati IUFD 7,7\%, BBLR 13,5\%, Dekompensasi kordis $0,9 \%$, lain - lain $77,8 \%$ sedangkan di RSKIA Kota Bandung $1,5 \%$ solusio plasenta, IUFD $6,8 \%$, BBLR 22,8\%, dekompensasi kordis $0,6 \%$ plasenta previa $1,2 \%$ dan lain lain $32,9 \%$.

\section{Pembahasan}

\section{Umur}

Usia pasien sangat mempengaruhi terjadinya peningkatan kasus preeklamsia. Usia 20-35 tahun merupakan usia yang optimum bagi ibuibu untuk melahirkan. Dalam berbagai penelitian kejadian preeklamsia memang terbanyak ditemukan pada usia $20-35$ tahun dan risiko meningkatnya kejadian preeklamsia pada ibu - ibu yang berusia $<20$ tahun dan $>35$ tahun.

Hasil penelitian Novida juga didapatkan bahwa sebagian besar responden yang mengalami pre eklamsia dengan umur lebih dari 35 tahun, karena umur tersebut memiliki kecenderungan pada kejadian preeklamsia dibandingkan dengan responden dengan umur antara $20-35$ tahun.
Usia kehamilan $<20$ tahun memiliki keadaan alat reproduksi yang belum siap untuk menerima kehamilan sehingga meningkatkan terjadinya keracunan kehamilan berupa preeklamsia. Sedangkan Usia kehamilan >35 tahun berisiko untuk terjadinya preeklamsia karena pada usia ini terjadi peningkatan kerusakan endotel vaskular karena proses penuaan dan terjadinya obstruksi pada lumen arteriolar oleh aterosis.

Menurut penelitian yang dilakukan Hinda (2016) bahwa ada pengaruh yang signifikan antara faktor usia dengan resiko terjadinya preeklampsia, hal tersebut dimungkinkan sebagian besarumur ibu adalah usia reproduksi (20-35 tahun). Ibu berumur antara 20-29 merupakan umur terendah penyumbang kematian ibu dan bayi, sementara ibu yang lebih muda atau lebih tua mempunyai resiko yang besar, kehamilan ibu dengan umur 16 tahun terjadi peningkatan resiko terjadi preeklampsi, umur $>35$ berada pada resiko tinggi dan $>40$ mempunyai resiko sangat tinggi.

\section{Paritas}

Paritas 1-4 merupakan paritas yang paling aman ditinjau dari sudut kematian maternal dan neonatal. Primigravida merupakan faktor risiko 
yang paling besar terhadap preeklamsia dan eklamsia. Menurut Zuspan (1991) sebanyak $85 \%$ preeklamsia terjadi pada kehamilan pertama. Penelitian yang dilakukan Hiett dkk (2001) menyatakan bahwa kejadian preeklamsia paling banyak terjadi pada primigravida yaitu sebanyak $62 \%$.

Seorang primigravida sering mengalami stress dalam menghadapi kehamilan. Strees tersebut merupakan akibat dari ibu tidak bisa beradaptasi terhadap kehamilan yang dapat disebabkan oleh beberapa faktor antara lain gangguan body image akibat perubahan bentuk tubuh selama kehamilan, ibu belum siap menghadapi kehamilannya, serta kurangnya informasi tentang proses kehamilan. Selain itu, emosi yang terjadi pada primigravida menyebabkan peningkatan pelepasan corticotropic-releasing hormone (CHG) oleh hipotalamus, yang kemudian menyebabkan peningkatan kortisol. Efek kortisol yaitu mempersiapkan tubuh untuk berespons terhadap semua stressor dengan meningkatkan respons simpatis, termasuk respons yang ditujukan untuk meningkatkan curah jantung dan mempertahankan tekanan darah.

$\begin{array}{crrr}\text { Menurut } & \text { Putri } & \text { Dyah } & \text { (2008) } \\ \text { menyatakan } & \text { bahwa } & \text { ibu } & \text { hamil }\end{array}$

primigravida memiliki risiko 3 kali untuk terkena preeklamsia/eklamsia. Hal ini didukung oleh penelitian Baktiyani dkk (2005) di Rumah Sakit Saiful Anwar Malang bahwa pada tahun 1997 ibu hamil primigravida dengan preeklamsia/eklamsia sebesar 3,6\% dan meningkat pada tahun 1999 menjadi $29 \%$ pada primigravida yang berumur kurang dari 35 tahun dan lebih dari 19 tahun. Artinya bahwa dari 100 kasus preeklamsia 29 kasus terjadi pada primigravida.

$$
\text { Penelitian Hinda }
$$
didapatkan ada pengaruh yang signifikan antara paritas dengan kejadian preeklamsia, ibu hamil paritas primigravida dan grandemultigravida mempunyai peluang 2.117 kali mengalami kejadian preeklampsia dibandingkan dengan ibu hamil multigravida.

Preeklamsia eklamsia lebih sering terjadi pada nullipara diduga karena adanya suatu mekanisme imunologik disamping endokrin dan genetik, pada kehamilan pertama pembentukan blocking antibodies terhadap antigen plasenta belum sempurna, yang makin sempurna pada kehamilan berikutnya.

Dalam New England Journal of Medicine disebutkan persalinan kedua dan ketiga adalah persalinan yang aman, 
tercatat bahwa kehamilan pertama berisiko terjadi preeklampsia 3,9\%; kehamilan kedua $1,7 \%$ dan kehamilan ketiga $1,8 \%$.

\section{Usia Kehamilan}

Barton dkk (1994) menangani 594 wanita yang mengalami hipertensi ringan. Usia kehamilan para wanita tersebut antara 24 sampai dengan 36 minggu dan seperempatnya mengalami proteinuria. Preeklamsia pada hipertensi kronik biasanya muncul pada usia kehamilan dini dibandingkan pada preeklamsia murni.

Penelitian yang dilakukan Lestariningsih (2018) bahwa usia kehamilan >37 minggu berpengaruh signifikan terhadap risiko preeklamsieklamsi pada kehamilan. Makin tua umur kehamilan, makin tinggi frekuensi terjadinya preeklampsi-eklamsi.

Penelitian oleh Kishwara di Bangladesh tahun 2005-2006 menunjukkan bahwa rerata usia gestasi pada pasien preeklamsia adalah $36,9 \pm$ 1,03 dan rerata usia gestasi pada pasien hamil normal adalah 38,27 $\pm 1,26$ minggu.13 Preeklamsia-eklamsia meningkatkan risiko terjadinya prematuritas pada neonatus. Prematuritas pada neonatus yang terjadi berhubungan dengan tingkat keparahan preeklamsia pada maternal. Upaya untuk pemeliharaan janin dilakukan apabila janin masih kurang bulan, tetapi jika kondisi maternal tidak memungkinkan untuk dilakukan pemeliharaan janin, maka dilakukan terminasi demi kesejahteraan ibu dan neonatus.

Secara fisiologi kehamilan normal, arteria spiralis yang terdapat pada desidua mengalami pergantian sel dengan trofoblas endovaskuler yang akan menjamin tetap terbukanya lumen untuk memberikan aliran darah tetap, nutrisi cukup dan O2 seimbang. Proses pergantian sel ini seharusnya pada trimester pertama, yaitu minggu ke-16 dengan perkiraan pembentukan plasenta telah berakhir. Invasi endovaskuler trofoblas terus berlangsung pada trimester kedua dan masuk ke dalam arteria miometrium. Hal ini menyebabkan pelebaran dan tetap terbukanya arteri sehingga kelangsungan aliran darah, nutrisi dan O2 tetap terjamin. Hal tersebut dibutuhkan janin dalam rahim. Invasi trimester kedua pada preeklampsi-eklampsi tidak terjadi sehingga terjadi hambatan pada saat memerlukan tambahan aliran darah untuk memberikan nutrisi dan $\mathrm{O} 2$ dan menimbulkan situasi "iskemia region uteroplasenter" pada sekitar minggu ke20. keadaan ini dapat menerangkan 
bahwa preeklampsi-eklampsi baru akan terjadi mulai minggu ke-20 kehamilan.

\section{Cara Persalinan}

Kala II harus dipersingkat dalam 24 jam dengan ekstraksi vakum atau forceps, jadi ibu dilarang mengedan (dilakukan oleh dokter ahli kandungan), jangan berikan methergin postpartum, kecuali bila terjadi perdarahan yang disebabkan atonia uteri; pemberian MgSO4 kalu tidak ada kontraindikasi, kemudian diteruskan dengan dosis 4 gr setiap 4 jam dalam 24 jam postpartum.

Pengelolaan persalinan pada kasus preeklamsia berat diupayakan persalinan dalam 24 jam. Bedah sesar dilakukan bila tidak ada koagulopati dan tersedia anestesi umum. Jika tidak tersedia anastesi umum, janin mati atau BBLR lakukan persalinan pervaginam. Sedangkan jika terjadi pematangan serviks baik lakukan induksi persalinan.

Resiko persalinan pada ibu dengan preeklampsia berat sangatlah tinggi karena dapat mengancam keselamatan ibu dan janin, bahkan dapat menjadi eklampsia, maka perlu dilakukan upaya yang optimal untuk menurunkan kejadian tersebut yaitu mengakhiri kehamilan dengan persalinan tindakan

Pada umur kehamilan <37 minggu bila tanda dan gejala tidak memburuk, kehamilan dapat dipertahankan sampai aterm tapi jika umur kehamilan >37 minggu persalinan ditunggu sampai timbul onset persalinan atau dipertimbangkan untuk melakukan induksi persalinan pada taksiran tanggal persalinan dan tidak menutup kemungkinan dapat dilakukan persalinan secara spontan.

\section{Komplikasi}

Penelitian yang dilakukan Kun Ika menyatakan bahwa ada hubungan antara pre eklampsia dengan bayi berat lahir rendah (BBLR) yang dilaksanakan di RSUD Gambiran Kota Kediri.

Komplikasi pada kasus-kasus preeklamsia dimungkinkan karena pemakaian obat anti hipertensi sebagai upaya memperlama kehamilan. Sibai dkk (1987) menyatakan bayi dengan hambatan pertumbuhan dua kali lebih sering dijumpai pada wanita yang mendapatkan labetolol dibandingkan dengan yang hanya rawat inap.

Pasien preeklamsia-eklamsia ternyata ditemukan bahwa rerata diameter arteriol spiralis miometrium lebih kecil dibandingkan dengan wanita hamil normal. Brosens dkk melaporkan dari 50 wanita hamil normal, rerata diameter arteriol spiralis miometrium adalah $500 \mu \mathrm{m}$ dan pada 36 wanita dengan eklamsia, rerata diameter arteriol spiralis miometrium adalah $300 \mu \mathrm{m}$. Hal 
ini menyebabkan nutrisi dan oksigenasi neonatus menjadi berkurang sehingga menyebabkan mortalitas dan morbiditas pada neonatus, spasme arteriola spiralis desidua yang menyebabkan menurunnya aliran darah ke plasenta yang akan mengakibatkan hipoksia pada plasenta yang kemudian akan membebaskan zatzat toksik dan radikal bebas yang akan merangsang terjadinya kerusakan sel endotel pembuluh darah dan menyebabkan stres oksidatif. Perfusi yang menurun akan mengakibatkan nutrisi ke janin terhambat, hal inilah yang menyebabkan terjadinya mortalitas dan morbiditas pada neonatus.

Bayi Berat Lahir Rendah salah satunya dapat disebabkan oleh gangguan pertumbuhan janin di dalam uterus yang dipengaruhi oleh kesehatan ibu. Pada preeklamsia atau eklamsia terjadi abnormalitas plasenta yang berakhir pada vasospasme dan cedera endotelial. Kegagalan invasi trofoblas gelombang kedua pada arteri spiralis menyebabkan kegagalan remodelling arteri spiralis yang mengakibatkan aliran darah uteroplasenta menurun. Hal tersebut dapat menyebabkan terjadinya hipoksia dan iskemia plasenta dan sering berakhir pada pertumbuhan janin terhambat. Gangguan aliran darah uteroplasenta menyebabkan penurunan suplai nutrien berupa glukosa, oksigen, asam amino, dan faktor pertumbuhan untuk janin yang berakibat pada berkurangnya pertumbuhan janin yang meliputi jaringan subkutan, rangka aksial, dan organ vital.

\section{Kesimpulan Saran}

Kejadian preeklamsia lebih banyak terjadi di daerah pantai (RSUD Gunung Jati Cirebon). Dari segi umur, insiden preeklamsia paling banyak terjadi pada usia > 35 tahun, pada paritas $0-1$ (primigravida), dengan usia kehamilan yang paling banyak mengalami preeklamsia 33 - 37 minggu. Cara persalinan yang paling sering dilakukan perabdominal pada pasien preeklamsia di daerah pantai dengan komplikasi paling sering terjadi adalah Berat Badan Lahir Rendah (BBLR).

Sedangkan di daerah pegunungan (RSKIA Kota Bandung) kejadian preeklamsia lebih banyak terjadi pada usia 30 - 35 tahun, pada paritas $>4$, di usia kehamilan > 37 minggu. Komplikasi yang paling banyak terjadi adalah BBLR. Diperlukan penelitian lebih lanjut mengenai kejadian preeklamsia serta fakta - fakta yang berhubungan baik di daerah pantai maupun pegunungan dengan populasi 
dan subjek studi yang lebih besar sehingga dapat dianalisis secara statistik.

\section{Ucapan Terima Kasih}

1. Prof. dr. Hidayat Widjajanegara, $\operatorname{SpOG}(\mathrm{K})$

2. dr. Ruswana Anwar, SpOG(K)

\section{Referensi}

Wiludjeng, R (2005). Gambaran penyebab kematian maternal di Rumah Sakit (RSUD pesisir selatan, RSUD Padang Pariaman, RSUD Sikka, RSUD Larantuka dan RSUD Serang). Puslitbang sistem dan kebijakan kesehatan Depkes RI. Diperoleh dari http://www.portalkalbe.com

Cunningham F, G. (2006). Obstetri William. Jakarta : EGC.

Sukandarrumidi. (2006). Geologi Medis. Yogyakarta : Gadjah Mada University Press.

Handayani PT, Mose JC. (2002). Pengaruh Faktor Umur, Paritas, dan Umur Kehamilan Terhadap Kejadian Preeklamsia Berat dan Eklamsia serta Hubungannya Terhadap Outcome Ibu dan Bayi Periode Januari 2001 - Desember 2002. Bandung : Bagian Obstetri dan Gynekologi FKUP RSHS Bandung.
Budiarto, E. (2004). Biostatistik untuk Kedokteran dan Kesehatan Masyarakat. Jakarta : EGC

Foster G M, Anderson B, G. (2006). Antropologi Kesehatan. Jakarta : Universitas Indonesia Press.

Saunders W, B. (2001). High Risk Pregnancy. Hart Court Publishers. Riris, P. (2012). Gambaran Luaran Hasil Persalinan Pada Pasien Preeklamsia - Eklamsia Di RSUD dr. Soedarso.Pontianak. FK Universitas Tanjung Pura. Diperoleh dari http//:media.neliti.com 